\title{
Prepubertal Development of GABAergic Transmission to Gonadotropin-Releasing Hormone (GnRH) Neurons and Postsynaptic Response Are Altered by Prenatal Androgenization
}

\author{
Tova Berg, ${ }^{1}{ }^{\circledR}$ Marina A. Silveira, ${ }^{4}$ and Suzanne M. Moenter ${ }^{1,2,3}$ \\ Departments of ${ }^{1}$ Molecular and Integrative Physiology, ${ }^{2}$ Internal Medicine, ${ }^{3}$ Obstetrics and Gynecology, University of Michigan, Ann Arbor, Michigan \\ 48109, and 4Department of Anatomy, Institute of Biomedical Sciences, University of São Paulo, CEP 05508-900, São Paulo, Brazil
}

Gonadotropin-releasing hormone ( $\mathrm{GnRH}$ ) neurons regulate reproduction through pulsatile $\mathrm{GnRH}$ release. Women with polycystic ovary syndrome (PCOS) have persistently elevated luteinizing hormone release frequency, reflecting GnRH release; this exacerbates hyperandrogenemia and disrupted reproductive cycles that are characteristic of this disorder. Clinical evidence suggests that neuroendocrine features of PCOS may manifest peripubertally. Adult mice prenatally exposed to androgens (PNA) mimic several reproductive features of PCOS. GnRH neurons from these mice have increased firing activity and receive increased GABAergic transmission, which is excitatory. When changes emerge during development is unknown. To study the typical postnatal development of GABAergic transmission and the effects of PNA treatment and sex, whole-cell voltage-clamp recordings were made of GABAergic postsynaptic currents (PSCs) in GnRH neurons in brain slices from prepubertal through adult control and PNA female and male mice. GABAergic transmission was present by 1 week of age in females and males and increased in frequency, reaching adult levels at 3 and 4 weeks, respectively. GABAergic PSC frequency was elevated in 3-week-old PNA versus control females. PSC frequency in both controls and PNA mice was activity independent, suggesting that PNA induces changes in synapse organization. PNA also alters the functional response of GnRH neurons to GABA. GABA induced firing in fewer neurons from 3-week-old PNA than control females; membrane potential depolarization induced by GABA was also reduced in cells from PNA mice at this age. PNA thus induces changes during development in the presynaptic organization of the GABAergic network afferent to GnRH neurons as well as the postsynaptic GnRH neuron response, both of which may contribute to adult reproductive dysfunction.

Key words: GABA; GnRH; gramicidin; PCOS; PNA

Significance Statement

The central neuronal network that regulates reproduction is overactive in polycystic ovary syndrome (PCOS), a leading cause of infertility. Recent evidence of neuroendocrine dysfunction in midpubertal girls suggests that the pathophysiological mechanisms underlying PCOS may arise before pubertal maturation. Prenatal exposure to androgens (PNA) in mice mimics several neuroendocrine features of PCOS. GABAergic transmission to gonadotropin-releasing hormone (GnRH) neurons is important for reproduction and is increased in adult PNA mice. The typical development of this network and when changes with PNA and sex arise relative to puberty are unknown. These studies provide evidence that PNA alters prepubertal development of the GABAergic network afferent to GnRH neurons, including both the presynaptic organization and postsynaptic response. These changes may contribute to reproductive dysfunction in adults.

\section{Introduction}

Gonadotropin-releasing hormone $(\mathrm{GnRH})$ neurons form the final common pathway for central regulation of reproduction. $\mathrm{GnRH}$ is released in pulses (Clarke and Cummins, 1982; Moenter et al., 1992). During the typical female reproductive cycle, shifts from low- to high-frequency GnRH release help to drive differential synthesis and the secretion of follicle-stimulating hormone (FSH) and luteinizing hormone ( $\mathrm{LH}$ ) from the pituitary (Wildt et 
al., 1981; Haisenleder et al., 1991). FSH and LH regulate ovarian follicle maturation and steroidogenesis (Baird et al., 1976; Zeleznik and Fairchild-Benyo, 1994). Steroid feedback in turn modulates GnRH/LH release (Leipheimer et al., 1984; Nippoldt et al., 1989; Moenter et al., 1990; Tilbrook et al., 1991; McCartney et al., 2002). GnRH neurons do not express detectable levels of most steroid hormone receptors (Watson et al., 1992; Huang and Harlan, 1993; Skinner et al., 2001); therefore, these signals are likely conveyed via steroid-sensitive presynaptic inputs (Wintermantel et al., 2006; Cheong et al., 2015).

The frequency of $\mathrm{LH}$ secretion (a bioassay for GnRH release) and steroid feedback regulation of $\mathrm{LH}$ release are both altered in women with polycystic ovary syndrome (PCOS). PCOS is a leading cause of infertility, conservatively affecting $8 \%$ of women of reproductive age (Goodarzi et al., 2011). Women with PCOS have persistently elevated $\mathrm{GnRH} / \mathrm{LH}$ release frequencies rather than cyclical shifts in pulse frequency (Burt Solorzano et al., 2012; McCartney and Marshall, 2016) and are less sensitive to progesterone negative feedback (Pastor et al., 1998). Increased GnRH release frequency contributes to the pathology of PCOS by altering $\mathrm{LH}$ and FSH levels, thus exacerbating the elevated ovarian androgen production and irregular menstrual cycles that are characteristic of this disorder. Manifestations of nascent PCOS are increasingly being detected at younger ages; for example, evidence of elevated LH pulse frequency and hyperandrogenemia may be see in midpubertal girls (Tanner stages 3-4; Blank et al., 2006; Shayya and Chang, 2010; Collins et al., 2014). These clinical findings suggest that antecedents of PCOS may arise during or even before pubertal development.

Exposure to androgens during prenatal development produces neuroendocrine features similar to those of PCOS in adult animals, including rodents, sheep, and rhesus macaques (Birch et al., 2003; Sullivan and Moenter, 2004; Abbott et al., 2005; Foecking et al., 2005). Adult female prenatally androgenized (PNA) mice have elevated $\mathrm{LH}$ pulse frequencies, increased testosterone levels, and disrupted estrous cycles (Sullivan and Moenter, 2004; Witham et al., 2012; Moore et al., 2015). GnRH neurons in brain slices from these mice have a higher firing rate (Roland and Moenter, 2011) and receive higher-frequency GABAergic transmission (Sullivan and Moenter, 2004; Roland and Moenter, 2011). GnRH neurons from control mice maintain high intracellular chloride levels even in adulthood and thus exhibit an excitatory response to GABA action via $\mathrm{GABA}_{\mathrm{A}}$ receptors $\left(\mathrm{GABA}_{\mathrm{A}}\right.$ Rs; DeFazio et al., 2002; Herbison and Moenter, 2011). Additionally, GABAergic fiber appositions to $\mathrm{GnRH}$ are increased in adult PNA mice (Moore et al., 2015). GABAergic afferents are important mediators of steroid feedback regulation of GnRH neuron function (Petersen et al., 2003; Sullivan and Moenter, 2005; Christian and Moenter, 2007; Pielecka-Fortuna and Moenter, 2010). Increases in GABAergic transmission could thus contribute to the increased GnRH neuron activity in the adult PNA mouse.

Despite the importance of GABAergic afferents in the regulation of GnRH neurons, little is known about either the typical

and Laura Burger for expert technical assistance; and Christopher McCartney, University of Virginia, for comments on the manuscript. We also thank James L. Kenyon, University of Nevada, Reno, for the Excel spreadsheet used to calculate junction potentials.

The authors declare no competing financial interests.

Correspondence should be addressed to Suzanne M. Moenter, Department of Molecular and Integrative Physiology, University of Michigan, 7725 Med Science II, 1137 East Catherine Street, Ann Arbor, MI 48109-5622. E-mail: smoenter@umich.edu.

DOI:10.1523/JNEUROSCI.2304-17.2018

Copyright $\odot 2018$ the authors $\quad 0270-6474 / 18 / 382284-11 \$ 15.00 / 0$ rates of GABAergic transmission across the pubertal transition or when differences attributable to sex or PNA exposure emerge. The prepubertal period and pubertal transition may be critical periods during which alterations in synaptic organization and/or function may have broad implications for adult reproductive physiology. We examined GABAergic synaptic transmission to $\mathrm{GnRH}$ neurons and GnRH neuron response to GABA in brain slices from prepubertal through adult female and male mice to understand the typical development of this network and the functional changes induced by PNA.

\section{Materials and Methods}

All reagents were purchased from Sigma-Aldrich unless noted.

Animals. GnRH-GFP mice (Suter et al., 2000) were bred in our colony. All mice were provided with water and Harlan 2916 chow ad libitum and were held on a 14:10 light/dark cycle with lights on at 4:00 A.M. Eastern Standard Time. To generate PNA mice, a GnRH-GFP mouse and a CD1 female mouse were paired for 1-3 weeks and then a stud male was introduced. Males were removed after pregnancy was established. PNA mice were generated by injecting pregnant GnRH-GFP dams with dihydrotestosterone (DHT; $225 \mu \mathrm{g}$, s.c., in sesame oil vehicle) on days 16-18 of gestation (day 1, copulatory plug observed). Controls (con) included mice from vehicle-treated or uninjected GnRH-GFP dams; as in previous studies (Roland and Moenter, 2011), no differences were observed between these groups, and they were combined for analysis. The CD1 mouse provided maternal and nutritional support that our observations indicate increase the survival times of PNA pups. Litter sizes were adjusted to $<15$ pups by culling CD1 pups to normalize nutrition. Pups not used for postnatal recordings were weaned at 3 weeks of age. Androgenization of PNA mice was confirmed in surviving female littermates by younger age of vaginal opening (con mice, $32.9 \pm 0.6 \mathrm{~d}$ old, $n=20 \mathrm{vs}$ PNA mice, $28.7 \pm 0.4 \mathrm{~d}$ old, $n=21 ; p<0.05$ ), disrupted estrous cycles (time spent in estrus: con mice, $23 \%, n=12$; vs PNA mice, $8 \%, n=12$; $p<0.05$ ) and greater anal-genital distance (con mice, $5.5 \pm 0.2, n=12$; vs PNA mice, $6.6 \pm 0.3, n=12 ; p<0.05)$. Female and male mice at postnatal ages $1,2,3$, and 4 weeks $\pm 1 \mathrm{~d}$ and adults (42-120 d old) were used for recording experiments. Experiments on female mice that had attained puberty were performed on diestrus. The Institutional Animal Care and Use Committee of the University of Michigan approved all procedures.

Brain slice preparation. All solutions were bubbled with $95 \% \mathrm{O}_{2} / 5 \%$ $\mathrm{CO}_{2}$ throughout the experiments and for at least $15 \mathrm{~min}$ before exposure to tissue. Brain slices were prepared through the preoptic area as previously described (DeFazio et al., 2002; Chu and Moenter, 2005; Glanowska and Moenter, 2015; Ruka et al., 2016). Briefly, brains were rapidly removed and placed in ice-cold sucrose saline containing the following (in $\mathrm{mm}$ ): 250 sucrose, $3.5 \mathrm{KCl}, 26 \mathrm{NaHCO}_{3}, 10 \mathrm{D}$-glucose, 1.25 $\mathrm{Na}_{2} \mathrm{HPO}_{4}, 1.2 \mathrm{MgSO}_{4}$, and $3.8 \mathrm{MgCl}_{2}$. Coronal slices $(300 \mu \mathrm{m})$ were made using a Leica BiosystemsVT12000S Vibratome. Slices were incubated at room temperature for $30 \mathrm{~min}$ in a 50:50 solution of sucrose saline and ACSF containing the following (in mM): $135 \mathrm{NaCl}, 3.5 \mathrm{KCL}, 26$ $\mathrm{NaHCO}_{3}, 10$ D-glucose, $1.25 \mathrm{Na}_{2} \mathrm{HPO}_{4}, 1.2 \mathrm{MgSO}_{4}$, and $2.5 \mathrm{CaCl}_{2}, 310$ $\mathrm{mOsm} / \mathrm{L}, \mathrm{pH}$ 7.4. Slices were then transferred to $100 \%$ ACSF at room temperature for $0.5-5 \mathrm{~h}$ before recording. Slices were used within $6 \mathrm{~h}$ of preparation.

Electrophysiology recording and data acquisition. Slices were transferred to a recording chamber and perfused with oxygenated ACSF at a rate of 3 $\mathrm{ml} / \mathrm{min}$ at $30 \pm 1^{\circ} \mathrm{C}$. ACSF contained $20 \mu \mathrm{M}$ CNQX and $20 \mu \mathrm{M} \mathrm{APV}$ (Tocris Bioscience) to block ionotropic glutamate receptors. When ionotropic receptors for both glutamate and GABA are blocked, no fast synaptic transmission is detected in GnRH neurons, suggesting that these inputs account for the vast majority of fast synaptic transmission (Sullivan et al., 2003). Recording pipettes were pulled from borosilicate glass pipettes (outer diameter, $1.65 \mathrm{~mm}$; inner diameter, $1.1 \mathrm{~mm}$; World Precision Instruments) using a P-97 puller (Sutter Instruments). Pipettes were filled with a solution containing (in $\mathrm{mM}$ ): $140 \mathrm{KCl}, 10$ HEPES, 5 EGTA, $0.1 \mathrm{CaCl}_{2}, 4 \mathrm{MgATP}$, and $0.4 \mathrm{NaGTP}$, pH 7.2, at $310 \mathrm{mOsm} / \mathrm{L}$. Pipettes with resistances of $2-4 \mathrm{M}$ when filled this pipette solution were 
used. All voltages reported were corrected for liquid junction potential during analysis. GnRH-GFP neurons were identified by brief illumination with $470 \mathrm{~nm}$ light using an Olympus BX51WI Microscope. Recordings were made using one channel of an EPC-10 Dual Patch-Clamp Amplifier and Patchmaster acquisition software (HEKA) running on a Macintosh G4 computer (Apple). Membrane currents were filtered at 6.5 $\mathrm{kHz}$ and digitized at $10 \mathrm{kHz}$. Cell location was noted and mapped to an atlas to determine whether cell location-based differences emerged (Paxinos and Franklin, 2001). No differences in response attributable to rostral-caudal and medial-lateral distributions were evident. No more than three cells were used per animal. The variability between GnRH neurons recorded from a single mouse was similar to the variability of GnRH neurons among mice.

GABAergic PSC recordings. Whole-cell voltage-clamp recordings were made following the formation of a high-resistance seal $(\geq 1.3 \mathrm{G} \Omega$ ) between the pipette tip and cell membrane. GABAergic spontaneous PSCs (sPSCs) were recorded at $-55 \mathrm{mV}$ (number of cells per group are shown in Table 1). In some cells, activity-independent miniature PSCs (mPSCs) were recorded in the presence of $1 \mu \mathrm{M}$ tetrodotoxin (TTX, Tocris) following the measurement of sPSCs. To monitor cell health and recording quality, input resistance $(>500 \mathrm{M} \Omega)$, series resistance $(<20 \mathrm{M} \Omega$ uncompensated, $<20 \%$ change during the analyzed recording period), holding current $(-60$ to $+5 \mathrm{pA})$, and membrane capacitance (stable) were measured every $2 \mathrm{~min}$ from the average of 16 traces recorded in response to a $5 \mathrm{mV}$ hyperpolarizing step; traces with synaptic activity were excluded from analyses (Table 2,3). Capacitance increased with age but was not altered by sex or PNA treatment. These changes would not be expected to affect the data reported, and no other changes in passive properties were observed.

GABA application. Local pressure application of GABA was accomplished as described previously (DeFazio et al., 2014). Pipettes were filled with $100 \mu \mathrm{M}$ GABA in a HEPES-buffered saline solution containing the following (in $\mathrm{mm}$ ): $150 \mathrm{NaCl}, 10 \mathrm{HEPES}, 10 \mathrm{D}$-glucose, $3.5 \mathrm{KCl}, 2.5$ $\mathrm{CaCl}_{2}$, and $1.3 \mathrm{MgCl} 2, \mathrm{pH} 7.2$ with $\mathrm{NaOH}$. This pipette was placed $\sim 15$ $\mu \mathrm{m}$ from the soma, and a pulse of 5-10 psi was delivered using a PV820 picospritzer (World Precision Instruments). To determine whether GABA induces firing activity in GnRH neurons, on-cell voltage-clamp recordings were made and the response to GABA was evaluated during a $150 \mathrm{~ms}$ window after rapid GABA application. This was repeated three times per cell with $\leq 30 \mathrm{~s}$ between measurements. Pressure application of the HEPES-buffered solution without GABA did not induce firing (data not shown).

To assess the membrane potential response to rapid GABA application, membrane potentials were measured in the on-cell configuration as described previously (Fricker et al., 1999; Verheugen et al., 1999; DeFazio et al., 2014). Briefly, membrane potential is calculated by measuring potassium current in response to a voltage ramp from -100 to $+200 \mathrm{mV}$ over $50 \mathrm{~ms}$. This method assumes that the intracellular concentration of potassium is similar to that in the pipette solution, resulting in a reversal potential for potassium $\left(E_{\mathrm{K}}\right)$ across the patch near $0 \mathrm{mV}$. Under these conditions, the only driving force for the potassium current is the potential difference across the patched cell membrane; thus, the ramp potential at which the leak-corrected potassium current is $0 \mathrm{pA}$ reveals the membrane potential of the cell. Repeating this procedure twice at $100 \mathrm{~ms}$ intervals allows the baseline membrane potential to be estimated, a puff of GABA applied locally, and membrane potential in response to GABA estimated. This entire process was repeated $4-12$ times per cell with $\geq 30$ $\mathrm{s}$ between measurements. The average of the measurements is reported for each cell.

Gramicidin perforated-patch recordings. Gramicidin perforated-patch recordings were performed as in the study by DeFazio et al. (2002) with minor modifications. Gramicidin stock solutions $(50 \mathrm{mg} / \mathrm{ml}$ in DMSO) were prepared weekly, protected from light, and kept at $4^{\circ} \mathrm{C}$. A working concentration $(50-100 \mu \mathrm{g} / \mathrm{ml})$ was made fresh for each cell in pipette solution and sonicated for 10-20 s immediately before use. Patch pipettes (2-4.5 M $\Omega$ ) were backfilled with $1.5-2.5 \mu$ l of gramicidin-free pipette solution followed by gramicidin solution. Two pipette solutions were used, one with high chloride levels and one with low chloride levels; values obtained with these two solutions will be similar if inadvertent patch rupture has not occurred. The low-chloride ( $1 \mathrm{mM}$ ) pipette solution consisted of the follow-
Table 1. Cells/group for sPSC recordings

\begin{tabular}{lcccc}
\hline Age (weeks) & Con + & PNA $q$ & Con 0 & PNA 0 \\
\hline 1 & 7 & 13 & 6 & 5 \\
2 & 13 & 8 & 7 & 5 \\
3 & 11 & 12 & 13 & 9 \\
4 & 11 & 15 & 11 & 10 \\
$>6$ & 9 & 13 & 6 & 10 \\
\hline
\end{tabular}

Table 2. Membrane properties of GnRH neurons

\begin{tabular}{|c|c|c|c|c|c|}
\hline Group & $\begin{array}{l}\text { Age } \\
\text { (weeks) }\end{array}$ & $\begin{array}{l}\text { Input } \\
\text { resistance }\end{array}$ & $\begin{array}{l}\text { Series } \\
\text { resistance }\end{array}$ & $\begin{array}{l}\text { Membrane } \\
\text { capacitance }\end{array}$ & $\begin{array}{l}\text { Holding } \\
\text { current }\end{array}$ \\
\hline \multirow[t]{5}{*}{$q$ Con } & 1 & $1205 \pm 265$ & $16.9 \pm 4.1$ & $9.6 \pm 2.9$ & $-33.9 \pm 8.4$ \\
\hline & 2 & $1063 \pm 541$ & $14.2 \pm 2.7$ & $12.5 \pm 2.8$ & $-42.5 \pm 15.3$ \\
\hline & 3 & $1022 \pm 236$ & $15.5 \pm 3.7$ & $12.5 \pm 3.0$ & $-36.8 \pm 16.2$ \\
\hline & 4 & $1193 \pm 336$ & $16.7 \pm 4.7$ & $12.2 \pm 3.9$ & $-34.4 \pm 16.6$ \\
\hline & $>6$ & $1263 \pm 354$ & $16.5 \pm 4.8$ & $13.3 \pm 2.9$ & $-32.0 \pm 15.0$ \\
\hline \multirow[t]{5}{*}{ @ PNA } & 1 & $1181 \pm 345$ & $16.6 \pm 3.2$ & $10.8 \pm 4.7^{a}$ & $-41.5 \pm 12.9$ \\
\hline & 2 & $1166 \pm 340$ & $14.5 \pm 3.6$ & $13.5 \pm 6.2$ & $-35.9 \pm 15.0$ \\
\hline & 3 & $1147 \pm 436$ & $14.9 \pm 4.5$ & $12.1 \pm 4.4$ & $-38.8 \pm 14.2$ \\
\hline & 4 & $1135 \pm 303$ & $13.9 \pm 4.1$ & $13.3 \pm 2.3^{b}$ & $-31.7 \pm 11.2$ \\
\hline & $>6$ & $1203 \pm 308$ & $16.0 \pm 5.1$ & $14.6 \pm 2.1^{b}$ & $-35.9 \pm 18.2$ \\
\hline \multirow[t]{5}{*}{$\widehat{O}$ Con } & 1 & $1293 \pm 279$ & $17.4 \pm 6.3$ & $14.1 \pm 9.2^{a}$ & $-35.7 \pm 12.1$ \\
\hline & 2 & $946 \pm 279$ & $15.6 \pm 2.1$ & $10.2 \pm 1.0^{a}$ & $-44.7 \pm 13.3$ \\
\hline & 3 & $1127 \pm 282$ & $16.2 \pm 3.3$ & $12.5 \pm 3.3^{a}$ & $-31.5 \pm 9.2$ \\
\hline & 4 & $989 \pm 279$ & $14.6 \pm 2.3$ & $12.2 \pm 2.7^{a}$ & $-43.0 \pm 20.8$ \\
\hline & $>6$ & $851 \pm 184$ & $15.1 \pm 4.8$ & $16.7 \pm 2.9^{b}$ & $-48.0 \pm 26.4$ \\
\hline \multirow[t]{5}{*}{ ठ̊ PNA } & 1 & $1180 \pm 312$ & $16.0 \pm 3.5$ & $8.4 \pm 2.7^{a}$ & $-41.8 \pm 20.7$ \\
\hline & 2 & $939 \pm 242$ & $16.1 \pm 4.9$ & $15.0 \pm 8.8^{b}$ & $-46.5 \pm 6.9$ \\
\hline & 3 & $921 \pm 330$ & $13.4 \pm 4.8$ & $13.3 \pm 6.5^{b}$ & $-45.9 \pm 12.9$ \\
\hline & 4 & $942 \pm 272$ & $15.5 \pm 4.4$ & $12.7 \pm 3.3$ & $-41.0 \pm 13.0$ \\
\hline & $>6$ & $1146 \pm 472$ & $15.1 \pm 4.6$ & $13.8 \pm 3.4^{b}$ & $-33.4 \pm 17.6$ \\
\hline
\end{tabular}

Values are the mean \pm SEM. Different lower case letters indicate differences with age within a group. Significant differences are defined as $p<0.05$. Values without letters are not different from any other age, sex, or treatment.

Table 3. Two-way ANOVA parameters for comparison of membrane properties among groups

\begin{tabular}{|c|c|c|c|c|}
\hline Groups & Parameter & Sex & Age & Interaction \\
\hline Con $q$ vs Con ô & $\begin{array}{l}\text { Input resistance } \\
\text { Series resistance } \\
\text { Capacitance } \\
\text { Holding current } \\
\text { Input resistance } \\
\text { Series resistance } \\
\text { Capacitance } \\
\text { Holding current }\end{array}$ & $\begin{array}{l}F_{(1,84)}=1.72 \\
F_{(1,84)}=0.03 \\
F_{(1,84)}=0.26 \\
F_{(1,84)}=0.97 \\
F_{(1,94)}=3.36 \\
F_{(1,94)}=1.52 \\
F_{(1,94)}=0.07 \\
F_{(1,94)}=0.03\end{array}$ & $\begin{array}{l}F_{(4,84)}=0.82 \\
F_{(4,84)}=0.42 \\
F_{(4,84)}=4.66^{* *} \\
F_{(4,84)}=0.14 \\
F_{(4,94)}=1.02 \\
F_{(4,94)}=0.83 \\
F_{(4,94)}=2.53^{*} \\
F_{(4,94)}=1.05\end{array}$ & $\begin{array}{l}F_{(4,84)}=1.56 \\
F_{(4,84)}=0.71 \\
F_{(4,84)}=1.92 \\
F_{(4,84)}=0.93 \\
F_{(4,94)}=0.92 \\
F_{(4,94)}=0.81 \\
F_{(4,94)}=0.29 \\
F_{(4,94)}=0.99\end{array}$ \\
\hline Groups & Parameter & Treatment & Age & Interaction \\
\hline Con $\widehat{o}$ vs PNA $\widehat{\sigma}$ & $\begin{array}{l}\text { Input resistance } \\
\text { Series resistance } \\
\text { Capacitance } \\
\text { Holding current } \\
\text { Input resistance } \\
\text { Series resistance } \\
\text { Capacitance } \\
\text { Holding current }\end{array}$ & $\begin{array}{l}F_{(1,102)}=0.07 \\
F_{(1,102)}=1.76 \\
F_{(1,102)}=0.03 \\
F_{(1,102)}=1.13 \\
F_{(1,73)}=0.11 \\
F_{(1,73)}=1.47 \\
F_{(1,73)}=0.01 \\
F_{(1,73)}=1.58\end{array}$ & $\begin{array}{l}F_{(4,102)}=0.49 \\
F_{(4,102)}=0.44 \\
F_{(4,102)}=2.38 \\
F_{(4,102)}=0.86 \\
F_{(4,73)}=2.02 \\
F_{(4,73)}=0.41 \\
F_{(4,73)}=2.71^{*} \\
F_{(4,73)}=1.92\end{array}$ & $\begin{array}{l}F_{(4,102)}=0.73 \\
F_{(4,102)}=0.70 \\
F_{(4,102)}=0.51 \\
F_{(4,102)}=0.32 \\
F_{(4,73)}=0.91 \\
F_{(4,73)}=1.81 \\
F_{(4,73)}=1.96 \\
F_{(4,73)}=0.53\end{array}$ \\
\hline
\end{tabular}

${ }^{*} p<0.05 ;{ }^{* *} p<0.01$.

ing (in mM): $139 \mathrm{~K}$ gluconate, $1 \mathrm{KCl}, 10$ HEPES, 5 EGTA, $0.1 \mathrm{CaCl}_{2}, 4$ $\mathrm{MgATP}$, and $0.4 \mathrm{NaGTP}, \mathrm{pH} 7.2$, at $310 \mathrm{mOsm} / \mathrm{L}$. For the high-chloride (140 $\mathrm{mM}$ ) pipette solution, $\mathrm{K}$ gluconate was replaced with $\mathrm{KCl}$. The membrane potential for recordings with 1 or $140 \mathrm{~mm}$ chloride were corrected for liquid junction potentials of 16.5 and $4.9 \mathrm{mV}$, respectively.

After obtaining a minimum resistance seal of $1 \mathrm{G} \Omega, 5 \mathrm{mV}$ hyperpolarizing steps from a holding potential of $-65 \mathrm{mV}$ were made in voltage clamp to monitor membrane perforation. Recordings were initiated 
A

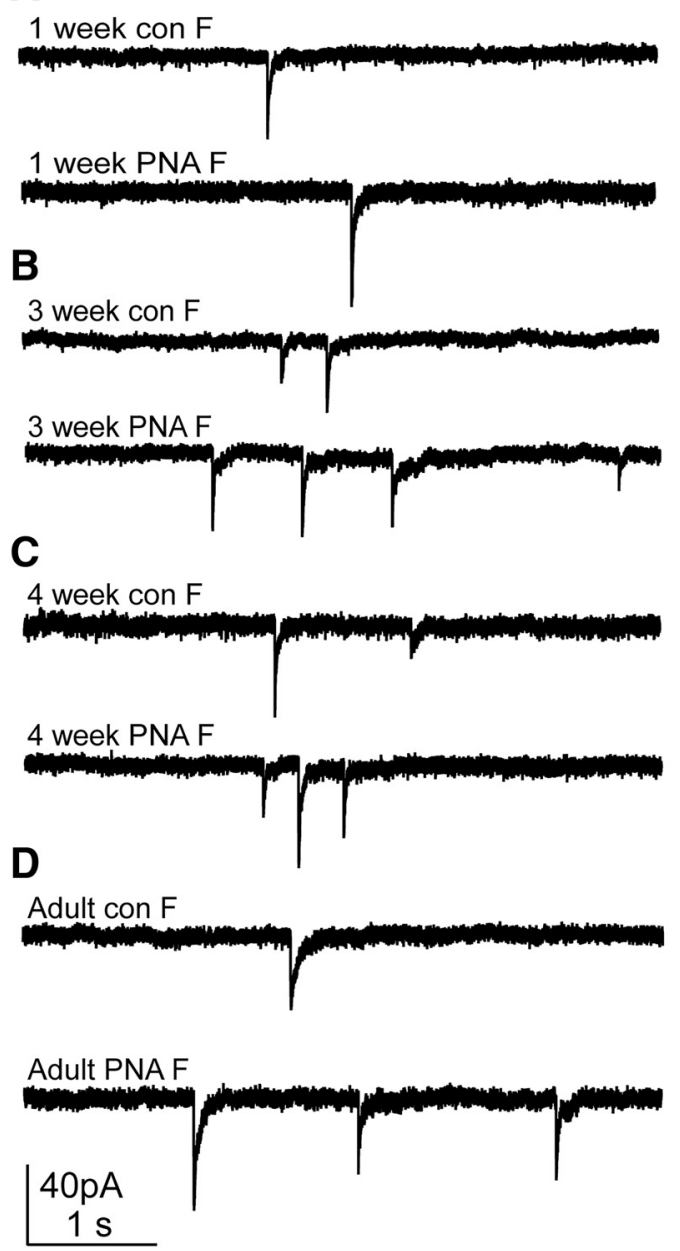

1 week con $M$

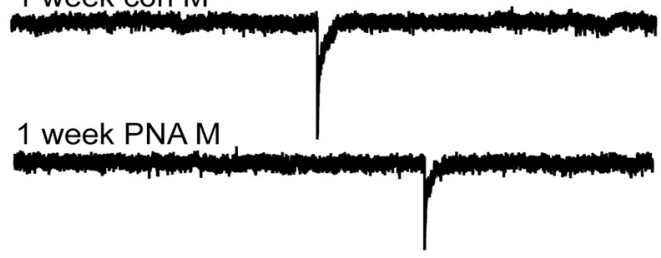

3 week con $M$

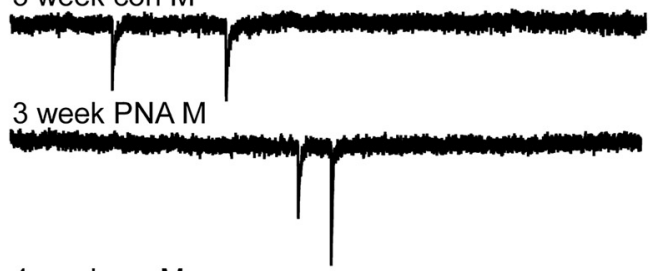

4 weekcon $\mathrm{M}$

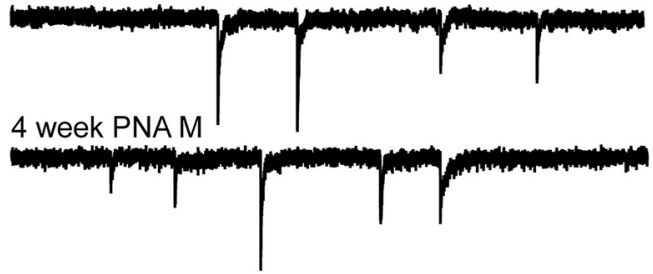

Adult con $\mathrm{M}$

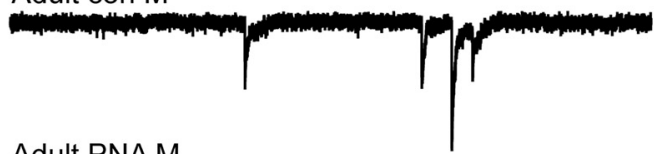

Adult PNA M

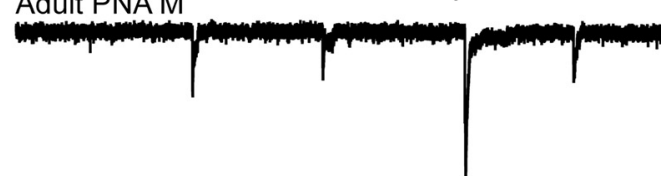

Figure 1. Representative recordings of GABAergic PSCs in GnRH neurons in female (F; left) and male (M; right) control (top) and PNA (bottom) mice at ages 1 week (A); 3 weeks (B); 4 weeks (C); and adults $>6$ weeks (D).

when the series resistance fell to $<50 \mathrm{M} \Omega$. Voltage steps $(-80$ to $+5 \mathrm{mV}$, $15 \mathrm{mV}$ interval, $500 \mathrm{~ms}$ ) were paired with local GABA application as described above to determine the reversal potential; GABA was applied $300 \mathrm{~ms}$ into the $500 \mathrm{~ms}$ voltage step to allow the membrane current to stabilize before drug application. A $5 \mathrm{mV}$ hyperpolarizing step was given before the start of each voltage step to determine series resistance; each step potential was independently corrected for voltage error resulting from series resistance in the analysis. Voltage steps and accompanying GABA application were delivered at $30 \mathrm{~s}$ intervals to ensure that applied GABA was cleared between measurements. Baseline current was measured just before GABA application, and GABA response was determined as the peak current following GABA application. The reversal potential was determined from the crossing of the current-voltage relationship of the baseline current and the GABA response using custom software written in IGOR Pro (Wavemetrics) and was verified by eye for each recording. Only reversals that were stable ( $<5 \mathrm{mV}$ variation) for at least two complete measurements were accepted. The rupture of perforated-patch recordings to whole-cell mode was detected by an abrupt decrease in access resistance, an increase in membrane capacitance, a broadening on capacitive transient shape, and a rapid change in the measured reversal potential (hyperpolarized with a $1 \mathrm{~mm}$ chloride pipette solution, depolarized with a $140 \mathrm{~mm}$ chloride pipette solution). Any recordings in which any of these changes were detected were discarded.

Analysis. PSC data were analyzed using custom software (Sullivan et al., 2003; DeFazio et al., 2014) written in IgorPro. Every PSC was visually confirmed. Frequency is the total number of events detected divided by the duration of the recording. Amplitude, rise time, decay, and full-width half- maximum (FWHM) are reported as the mean \pm SEM of all events in a recording. Rise time was quantified from baseline to half of the maximum amplitude of the PSC. Decay time was calculated as the time between $90 \%$ and $10 \%$ of the maximum current amplitude.

Statistics. Data are reported as the mean \pm SEM. Data were examined for normal distribution using the Shapiro-Wilk test. Statistical analyses were performed (Prism, GraphPad Software) with tests dictated by data distribution and experimental design; specific tests are indicated in the figure legends and tables. For age and sex comparisons, two-way ANOVA followed by Fisher's least significant difference (LSD) post hoc was used; this choice was justified by the large number of comparisons made (i.e., 45 different comparisons between either sex or treatment at five different ages). $p<0.05$ was accepted as significant but all $p$ values $<0.1$ are reported.

\section{Results}

GABAergic transmission to GnRH neurons occurs before puberty in females and males

Whole-cell voltage-clamp recordings of spontaneous GABAergic PSC frequency in GnRH neurons were made in brain slices from 1-, 2-, 3-, and 4-week-old and adult female and male control and PNA mice. Representative recordings are shown in Figure 1, and group comparisons are shown in Figure 2 and Table 4. Lowfrequency GABAergic transmission was observed at 1 week of age in all cells studied. In cells from control females, GABAergic transmission frequency increased between 2 and 3 weeks of age $(p<0.05$; Fig. 2A). In cells from control males, an increase was 

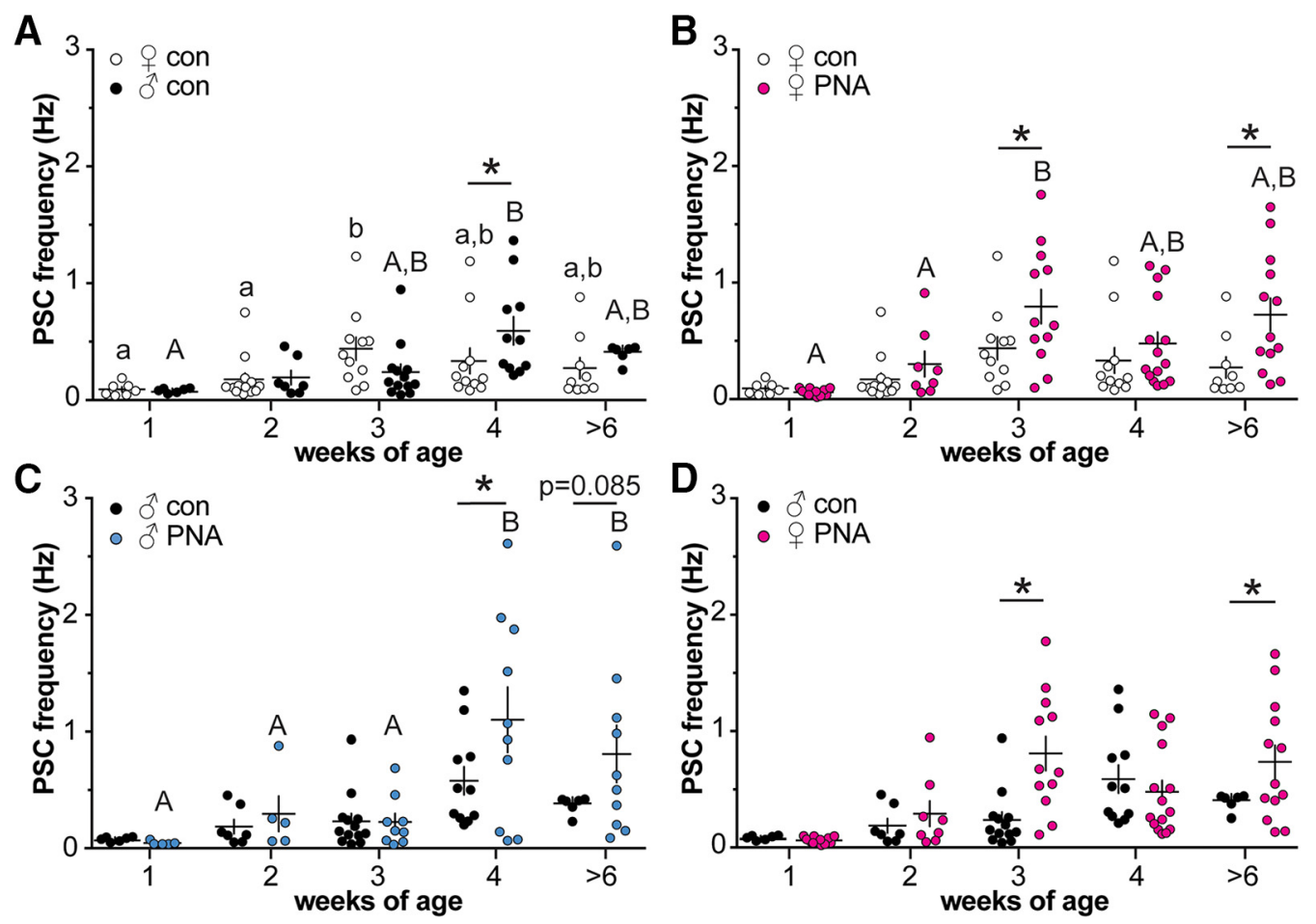

Figure 2. Spontaneous GABAergic transmission frequency to GnRH neurons changes throughout the prepubertal period in both sexes and is altered by PNA. $A-D$, Individual values and mean \pm SEM of GABAergic PSC frequency at 1, 2,3, and 4 weeks and adults at $>6$ weeks. $\boldsymbol{A}$, Control females (open circles) and males (black circles). $\boldsymbol{B}$, Control and PNA (magenta circles) females. $\boldsymbol{C}$, Control and PNA (blue circles) males. D, PNA females and control males. Comparisons made using two-way ANOVA/Fisher's LSD. Different letters of the same case indicate $p<0.05$ with age within a group. ${ }^{*} p<0.05$ between groups at each age.

Table 4. Two-way ANOVA parameters for comparison of sPSC and mPSC frequency and amplitude among groups

\begin{tabular}{llll}
\hline $\begin{array}{l}\text { Parameter } \\
\text { (figure displaying data) }\end{array}$ & Sex/treatment & Age & Interaction \\
\hline sPSC frequency (Fig. 2A) & $F_{(1,84)}=1.72$ & $F_{(4,84)}=5.64^{* * *}$ & $F_{(4,84)}=2.20^{*}$ \\
sPSC amplitude (Fig. 3A) & $F_{(1,84)}=0.17$ & $F_{(4,84)}=1.76$ & $F_{(4,84)}=1.30$ \\
sPSC frequency (Fig. 2B) & $F_{(1,102)}=9.45^{* *}$ & $F_{(4,102)}=8.44^{* * * *}$ & $F_{(4,102)}=1.57$ \\
sPSC amplitude (Fig. 3B) & $F_{(1,102)}=0.01$ & $F_{(4,102)}=0.5$ & $F_{(4,102)}=0.7$ \\
sPSC frequency (Fig. 2C) & $F_{(1,73)}=3.63^{*}$ & $F_{(4,73)}=7.77^{* * *}$ & $F_{(4,73)}=1.24$ \\
sPSC amplitude (Fig. 3O) & $F_{(1,73)}=0.07$ & $F_{(4,73)}=3.03^{*}$ & $F_{(4,73)}=0.88$ \\
sPSC frequency (Fig. 2D) & $F_{(1,94)}=6.37^{*}$ & $F_{(4,94)}=7.14^{* * *}$ & $F_{(4,94)}=3.73^{* *}$ \\
sPSC amplitude (Fig. 3D) & $F_{(1,94)}=0.20$ & $F_{(4,94)}=0.82$ & $F_{(4,94)}=1.80$ \\
mPSC frequency (Fig. 5A) & $F_{(1,43)}=3.63^{*}$ & $F_{(3,43)}=2.78^{*}$ & $F_{(3,43)}=1.47$ \\
mPSC amplitude (Fig. 5B) & $F_{(1,43)}=0.37$ & $F_{(3,43)}=0.61$ & $F_{(3,43)}=1.62$ \\
\hline
\end{tabular}

${ }^{*} p<0.05 ;{ }^{* *} p<0.01 ;{ }^{* * *} p<0.001 ;{ }^{* * *} p<0.0001$.

not observed until 4 weeks of age $(p<0.05)$. PSC frequency was higher in males than females at 4 weeks of age $(p<0.05)$.

PNA alters prepubertal development of GABAergic transmission to GnRH neurons in females and males

In cells from PNA females, GABAergic transmission frequency increased between 2 and 3 weeks of age as in controls, but the increase was more robust in PNA females (Fig. $2 B$ ). As a result, PSC frequency was elevated in cells from PNA compared with control females at 3 weeks of age $(p<0.05)$; this increase was maintained in adults $(p<0.05)$, confirming previous observations (Sullivan and Moenter, 2004). In males, GABAergic transmission frequency was increased at 4 weeks of age in cells from PNA compared with control males $(p<0.05)$, but not in adulthood ( $p=0.085$; Fig. $2 C$ ). To address the question of whether or not GABAergic transmission in PNA females reflects masculinization of the network, we compared PNA females to control males
(Fig. 2D). Cells from PNA females had higher GABAergic PSC frequency than cells from control males at 3 weeks of age $(p<0.05)$, and in adults $(p<0.05)$. GABAergic transmission in cells from PNA females thus showed a different pattern of prepubertal development from control males. There was no effect of age, sex, or treatment on GABAergic PSC amplitude (Fig. 3, Table 4). There was no overall trend with age, sex, or treatment in sPSC kinetics (Tables 5, 6). The FWHM was smaller at 4 weeks in control females and thus was elevated in controls at 2 weeks of age and in adults.

\section{The frequency of GABAergic transmission to GnRH neurons is activity independent}

Increased frequency of neurotransmission with postnatal development or PNA treatment could result from increased presynaptic activity and/or increased synaptic connectivity to $\mathrm{GnRH}$ neurons. To distinguish between these mechanisms, the fast voltage-gated sodium channel blocker TTX was added during recordings to isolate activity-independent neurotransmission, which is proportional to the number of functional synaptic connections (Auger and Marty, 2000; Kaeser and Regehr, 2014). As with sPSCs, mPSC frequency was increased in adult PNA females compared with controls; in 3-week-old females, mPSC frequency did not meet the criteria for statistical significance $(p=0.104$; Fig. 4A, Table 4). Neither the amplitude nor the kinetics of mPSCs differed with age or PNA treatment (Fig. 4B, Tables 4, 7, 8). Similarly, comparison of sPSC and mPSC frequency and amplitude in the same cell revealed no difference with age or PNA treatment (Fig. 4C,D, Table 9).

PNA alters the functional response of $\mathrm{GnRH}$ neurons from prepubertal female mice to acutely applied GABA

Because our main interest was in examining potential neurobiological mechanisms underlying PCOS, further studies were con- 

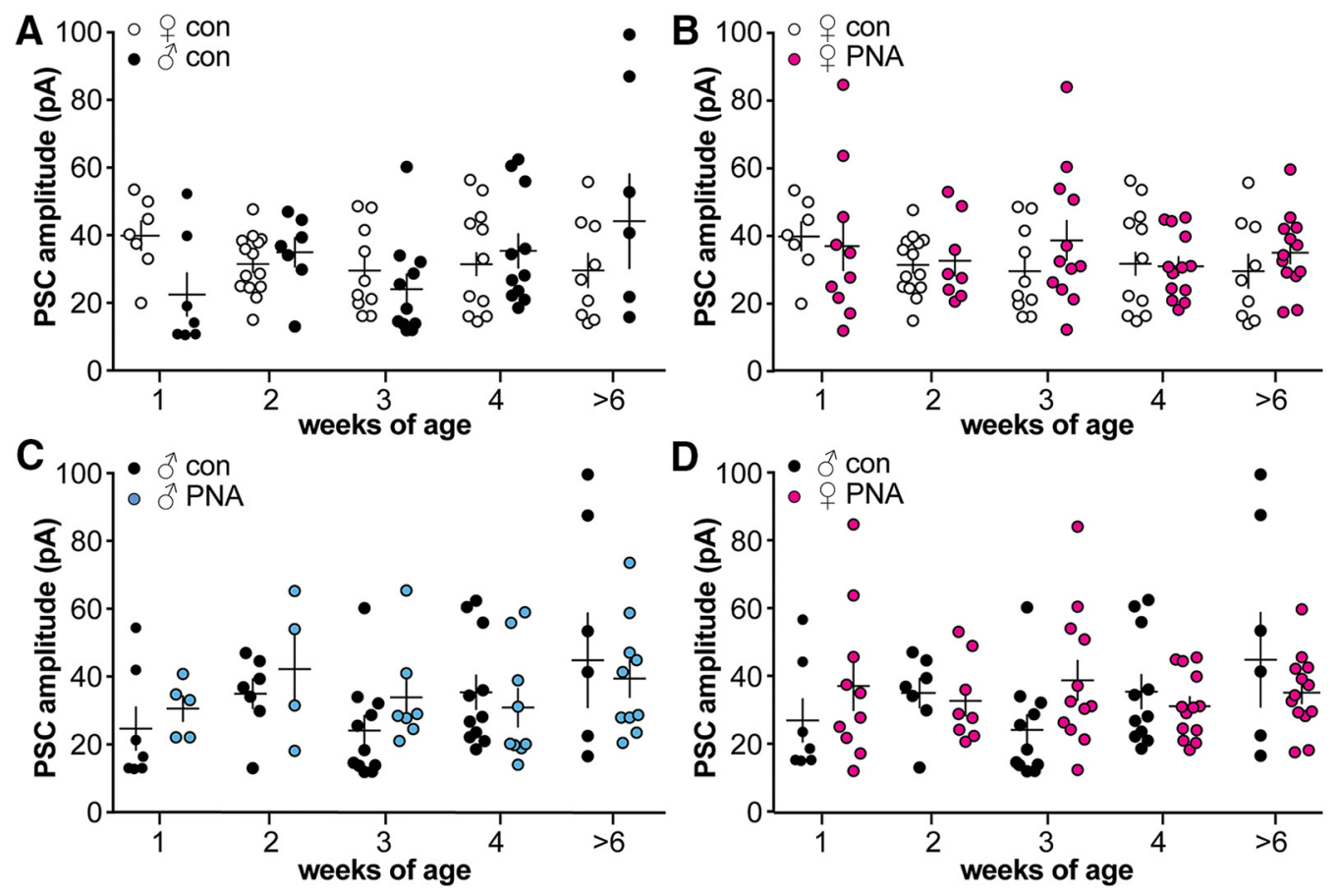

Figure 3. The amplitude of GABAergic sPSCs is not altered by PNA or sex. A-D, Individual values and mean \pm SEM (crosses) of GABAergic PSC amplitude at $1,2,3$, and 4 weeks and adults at $>6$ weeks. No differences were seen when analyzed using a two-way ANOVA/Fisher's LSD. $\boldsymbol{A}$, Control females (open circles) and males (black circles). $\boldsymbol{B}$, Control and PNA (magenta circles) females. C, Control and PNA (blue circles) males. D, PNA females and control males.

Table 5. Kinetic parameters of GABA sPSCs in GnRH neurons

\begin{tabular}{|c|c|c|c|c|}
\hline Group & Age (weeks) & Rise time (ms) & Decay (ms) & FWHM (ms) \\
\hline \multirow[t]{5}{*}{ q Con } & 1 & $0.37 \pm 0.06$ & $17.2 \pm 2.2$ & $5.99 \pm 0.75$ \\
\hline & 2 & $0.38 \pm 0.06$ & $18.8 \pm 1.0$ & $6.72 \pm 0.53^{a}$ \\
\hline & 3 & $0.52 \pm 0.08$ & $17.0 \pm 1.4$ & $5.42 \pm 0.32$ \\
\hline & 4 & $0.49 \pm 0.09$ & $19.2 \pm 1.5$ & $4.17 \pm 0.65^{b}$ \\
\hline & $>6$ & $0.43 \pm 0.11$ & $19.4 \pm 1.5$ & $6.41 \pm 0.64^{a}$ \\
\hline \multirow[t]{5}{*}{ @ PNA } & 1 & $0.52 \pm 0.17$ & $18.8 \pm 3.5$ & $5.94 \pm 0.57$ \\
\hline & 2 & $0.50 \pm 0.10$ & $23.1 \pm 2.4$ & $6.69 \pm 0.57$ \\
\hline & 3 & $0.32 \pm 0.07$ & $18.4 \pm 1.7$ & $4.99 \pm 0.58$ \\
\hline & 4 & $0.49 \pm 0.05$ & $17.4 \pm 1.0$ & $5.92 \pm 0.38$ \\
\hline & $>6$ & $0.42 \pm 0.07$ & $20.9 \pm 1.0$ & $6.02 \pm 0.82$ \\
\hline \multirow{5}{*}{$\widehat{O}$ Con } & 1 & $0.62 \pm 0.14$ & $22.6 \pm 3.2$ & $7.57 \pm 0.13$ \\
\hline & 2 & $0.40 \pm 0.08$ & $20.4 \pm 3.0$ & $6.69 \pm 0.57$ \\
\hline & 3 & $0.31 \pm 0.10$ & $18.2 \pm 2.8$ & $7.73 \pm 1.06$ \\
\hline & 4 & $0.33 \pm 0.09$ & $20.6 \pm 2.0$ & $5.92 \pm 0.38$ \\
\hline & $>6$ & $0.22 \pm 0.09$ & $20.7 \pm 1.5$ & $6.02 \pm 0.82$ \\
\hline \multirow[t]{5}{*}{ § PNA } & 1 & $0.35 \pm 0.08$ & $23.3 \pm 2.8$ & $6.39 \pm 0.61$ \\
\hline & 2 & $0.29 \pm 0.09$ & $25.2 \pm 0.9$ & $8.30 \pm 0.59$ \\
\hline & 3 & $0.57 \pm 0.05$ & $18.2 \pm 2.7$ & $5.38 \pm 0.52$ \\
\hline & 4 & $0.48 \pm 0.08$ & $20.2 \pm 1.1$ & $6.76 \pm 0.51$ \\
\hline & $>6$ & $0.36 \pm 0.05$ & $21.9 \pm 2.2$ & $5.99 \pm 0.46$ \\
\hline
\end{tabular}

Values are the mean \pm SEM. Different lower case letters indicate differences with age within a group. Significant differences defined as $p<0.05$. Values without letters are not different from any other age, sex, or treatment.

fined to females. Increased GABAergic transmission frequency during development could induce compensatory changes within GnRH neurons to alter the response to GABA; alternatively, the altered response of GnRH neurons to GABA could lead to changes in their presynaptic network. We hypothesized that PNA affects the functional response of $\mathrm{GnRH}$ neurons to $\mathrm{GABA}_{\mathrm{A}}$ receptor activation. To examine this, we first measured firing during an acute local application of exogenous GABA. This approach allows for rapid saturation of $\mathrm{GABA}_{\mathrm{A}}$ receptors with minimal receptor desensitization to study the membrane response to
Table 6. Two-way ANOVA parameters for comparison of GABA sPSC kinetics among groups

\begin{tabular}{|c|c|c|c|c|}
\hline Groups & Parameter & Sex & Age & Interaction \\
\hline on + vs Con $0 \hat{~}$ & $\begin{array}{l}\text { Rise time } \\
\text { Decay } \\
\text { FWHM } \\
\text { Rise time } \\
\text { Decay } \\
\text { FWHM }\end{array}$ & $\begin{array}{l}F_{(1,84)}=3.24 \\
F_{(1,84)}=2.86 \\
F_{(1,84)}=2.10 \\
F_{(1,94)}=4.48^{*} \\
F_{(1,94)}=0.30 \\
F_{(1,94)}=0.20\end{array}$ & $\begin{array}{l}F_{(4,84)}=0.30 \\
F_{(4,84)}=0.60 \\
F_{(4,84)}=0.22 \\
F_{(4,94)}=1.40 \\
F_{(4,94)}=0.96 \\
F_{(4,94)}=0.16\end{array}$ & $\begin{array}{l}F_{(4,84)}=1.04 \\
F_{(4,84)}=0.33 \\
F_{(4,84)}=0.23 \\
F_{(4,94)}=0.40 \\
F_{(4,94)}=0.79 \\
F_{(4,94)}=0.17\end{array}$ \\
\hline iroups & Paran & Treatment & Age & Interaction \\
\hline n ô vs PNA ठ઼ & $\begin{array}{l}\text { Rise time } \\
\text { Decay } \\
\text { FWHM } \\
\text { Rise time } \\
\text { Decay } \\
\text { FWHM }\end{array}$ & $\begin{array}{l}F_{(1,67)}=0.08 \\
F_{(1,102)}=1.84 \\
F_{(1,102)}=0.05 \\
F_{(1,73)}=2.00 \\
F_{(1,73)}=0.41 \\
F_{(1,73)}=0.30\end{array}$ & $\begin{array}{l}F_{(4,67)}=0.30 \\
F_{(4,102)}=1.68 \\
F_{(4,102)}=3.12^{*} \\
F_{(4,73)}=1.13 \\
F_{(4,73)}=2.21 \\
F_{(4,73)}=0.40\end{array}$ & $\begin{array}{l}F_{(4,67)}=1.29 \\
F_{(4,102)}=1.14 \\
F_{(4,102)}=0.65 \\
F_{(4,73)}=1.86 \\
F_{(4,73)}=0.60 \\
F_{(4,73)}=0.40\end{array}$ \\
\hline
\end{tabular}

$\overline{{ }^{*} p}<0.05$.

GABA, but does produce a longer exposure to transmitter than synaptic release provides (Fig. 5A). The on-cell configuration was used to avoid disrupting the intracellular chloride concentration, upon which the response to activation of the $\mathrm{GABA}_{\mathrm{A}}$ receptor depends (Succol et al., 2012). As reported previously (DeFazio et al., 2002; Sullivan et al., 2003), GABA induces firing in $\mathrm{GnRH}$ neurons from adult control females (Fig. $5 B, F)$. In adults, PNA did not affect the GnRH neuron firing response to GABA (Fig. 5C,F). During development, GABA evoked firing in the majority of GnRH neurons (96\%, 27 of 28 neurons) from control prepubertal mice (Fig. $5 D, F)$. In contrast, only $59 \%$ of GnRH neurons (13 of 22 neurons) from PNA mice fired in response to GABA during development (Fig. $5 E, F ; p<0.05$ vs cons). Lack of response was concentrated at 3 weeks of age, with only $33 \%$ of GnRH neurons ( 3 of 
A

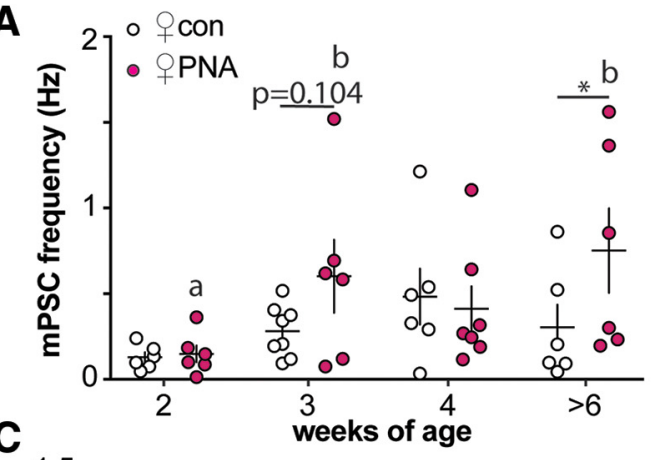

C

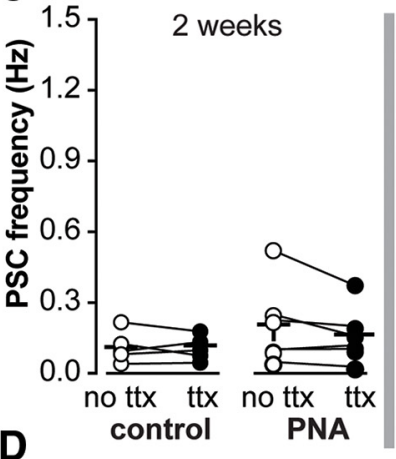

B 100 \% 9 con
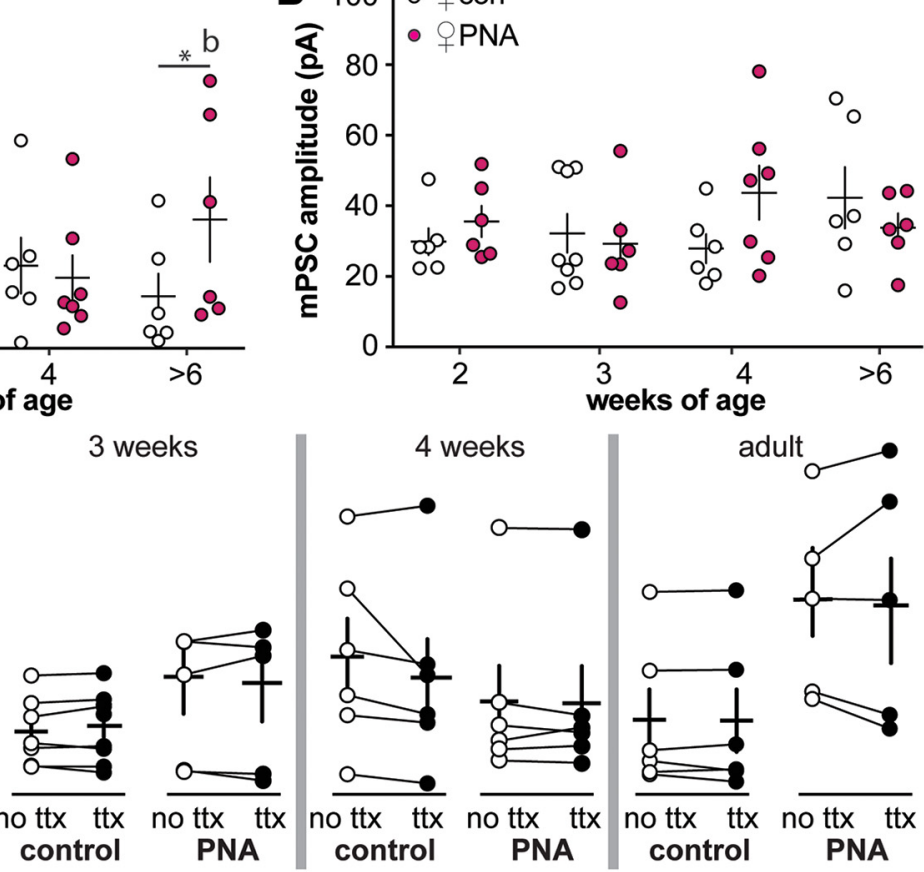
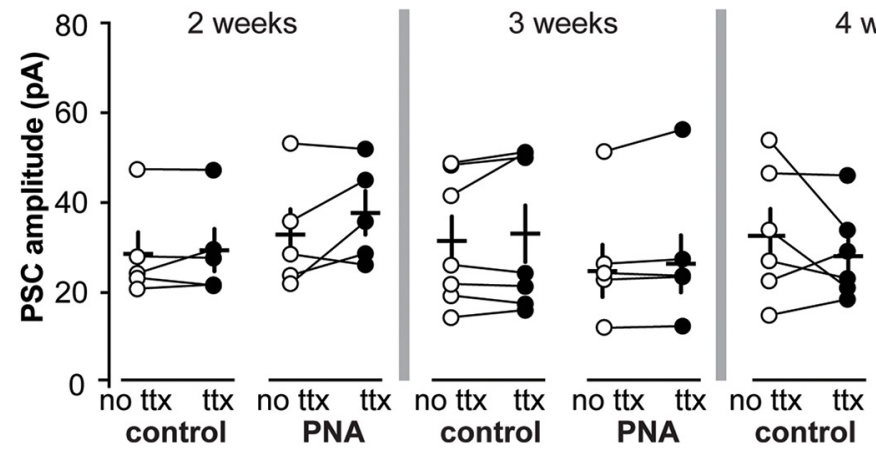

4 weeks

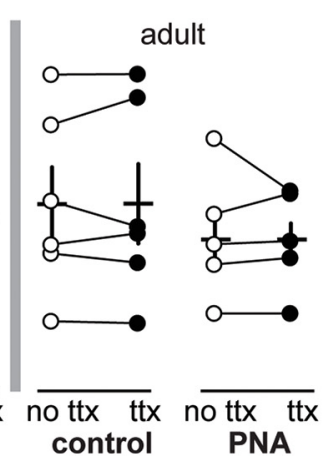

Figure 4. Activity-independent GABAergic transmission to GnRH neurons does not change throughout the prepubertal period or with PNA treatment in females. Individual values and mean \pm SEM (crosses) of mPSC frequency $(\boldsymbol{A})$ and $\mathrm{mPSC}$ amplitude $(\boldsymbol{B})$ at 2, 3, and 4 weeks and adults $>6$ weeks. Data for control females (open circles) and PNA females (magenta circles) were compared with two-way ANOVA/Fisher's LSD. Different lower case letters indicate differences with age within a group. ${ }^{*} p<0.05$ between groups at each age. $C, D, G A B A$ ergic PSC frequency $(\boldsymbol{C})$ and amplitude (D) in cells under control conditions (no TTX, open circles) and in the presence of $1 \mu \mathrm{m} \mathrm{TTX} \mathrm{(ttx,} \mathrm{closed} \mathrm{circles).} \mathrm{Data} \mathrm{for} \mathrm{each} \mathrm{age} \mathrm{were} \mathrm{compared} \mathrm{with} \mathrm{two-way} \mathrm{repeated-measures} \mathrm{ANOVA/Fisher's}$ LSD. Lines connect measurements made with and without TTX in the same cell.

Table 7. Kinetic parameters of GABA mPSCs in GnRH neurons

\begin{tabular}{lclll}
\hline Group & Age (weeks) & Rise time (ms) & Decay (ms) & FWHM (ms) \\
\hline q Con & 2 & $0.41 \pm 0.22$ & $22.40 \pm 5.06$ & $6.60 \pm 0.96$ \\
& 3 & $0.31 \pm 0.20$ & $20.61 \pm 4.04$ & $5.10 \pm 0.62$ \\
& 4 & $0.49 \pm 0.40$ & $22.05 \pm 2.67$ & $5.28 \pm 0.33$ \\
& $>$ & $0.29 \pm 0.17$ & $20.63 \pm 3.66$ & $6.18 \pm 0.99$ \\
क PNA & 2 & $0.60 \pm 0.33$ & $17.29 \pm 7.28$ & $5.74 \pm 0.22$ \\
& 3 & $0.50 \pm 0.40$ & $18.84 \pm 6.54$ & $6.61 \pm 0.61$ \\
& 4 & $0.38 \pm 0.25$ & $20.12 \pm 5.59$ & $6.49 \pm 0.38$ \\
& $>6$ & $0.37 \pm 0.25$ & $23.17 \pm 4.40$ & $7.27 \pm 0.55$ \\
\hline
\end{tabular}

Values are the mean \pm SEM. No differences were observed among groups.

9 neurons) firing in response to GABA ( $p<0.05$ vs con) vs $83 \%$ of cells ( 5 of 6 cells) from 2 -week-old PNA females and $71 \%$ of cells ( 5 of 7 cells) from 4 -week-old PNA females (Fig. $5 F)$. The percentage of firing cells was not different between PNA and control mice at 2 weeks of age $(p=0.462)$ or 4 weeks of age $(p>0.99)$. There were no changes in input resistance or capacitance with PNA that would contribute to the observed differences (Tables 2, 3).
Table 8. Two-way ANOVA parameters for comparison of GABA mPSC kinetics in control versus PNA females

\begin{tabular}{lllll}
\hline Groups & Parameter & Treatment & Age & Interaction \\
\hline Con + vs PNA $q$ & Rise time & $F_{(1,43)}=0.341$ & $F_{(4,43)}=0.923$ & $F_{(4,43)}=0.206$ \\
& Decay & $F_{(1,43)}=0.808$ & $F_{(4,43)}=2.24$ & $F_{(4,43)}=1.53$ \\
& FWHM & $F_{(1,43)}=0.161$ & $F_{(4,43)}=2.12$ & $F_{(4,43)}=0.0929$ \\
\hline
\end{tabular}

No differences were observed among groups.

GABA-induced membrane potential depolarization of GnRH neurons is blunted in cells from 3-week-old PNA mice

The altered firing response of $\mathrm{GnRH}$ neurons to GABA in prepubertal PNA mice is likely attributable to changes in the membrane potential response. GABA-induced current may depolarize, hyperpolarize, or have no effect on membrane potential. To determine whether PNA changes the membrane response to GABA, we measured the membrane potential before and during response to acutely applied GABA. There was no difference in the baseline membrane potential of $\mathrm{GnRH}$ neurons from female mice at any age or with prenatal treatment (Table 10). GABA induced membrane depolarization in 
Table 9. Two-way repeated-measures ANOVA parameters for comparison of sPSCs and $\mathrm{mPSCs}$

\begin{tabular}{|c|c|c|c|c|c|c|}
\hline Factor & Age (weeks) & Treatment & TTX & Interaction & $\operatorname{CON}(n)$ & PNA $(n)$ \\
\hline \multirow[t]{4}{*}{ Frequency } & 2 & $F_{(1,9)}=0.8$ & $F_{(1,9)}=2.3$ & $F_{(1,9)}=1.4$ & 5 & 6 \\
\hline & 3 & $F_{(1,10)}=1.0$ & $F_{(1,10)}=0.3$ & $F_{(1,10)}=0.08$ & 7 & 6 \\
\hline & 4 & $F_{(1,10)}=0.5$ & $F_{(1,10)}=2.5$ & $F_{(1,10)}=1.8$ & 6 & 6 \\
\hline & $>6$ & $F_{(1,9)}=4.5$ & $F_{(1,9)}=0.07$ & $F_{(1,9)}=0.15$ & 6 & 5 \\
\hline \multirow[t]{4}{*}{ Amplitude } & 2 & $F_{(1,9)}=0.6$ & $F_{(1,9)}=2.9$ & $F_{(1,9)}=1.5$ & 5 & 6 \\
\hline & 3 & $F_{(1,10)}=0.7$ & $F_{(1,10)}=3.2$ & $F_{(1,10)}=0.01$ & 7 & 6 \\
\hline & 4 & $F_{(1,10)}=0.8$ & $F_{(1,10)}=0.1$ & $F_{(1,10)}=2.8$ & 6 & 6 \\
\hline & $>6$ & $F_{(1,9)}=0.79$ & $F_{(1,9)}=0.01$ & $F_{(1,9)}=0.001$ & 6 & 5 \\
\hline
\end{tabular}

No differences were observed among groups.

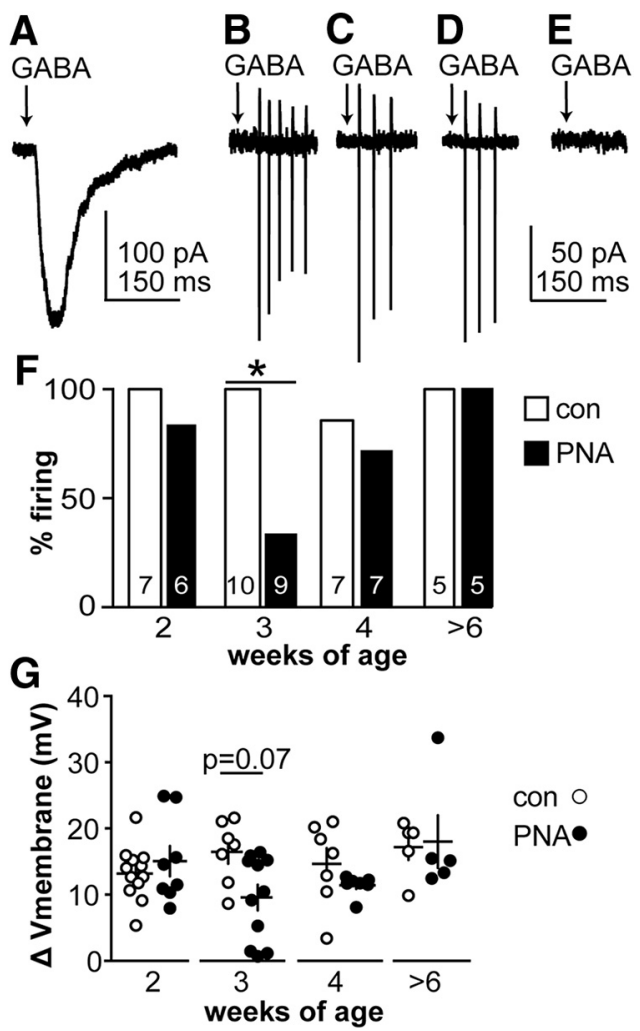

Figure 5. Response of GnRH neurons from PNA mice to acute GABA application is blunted at 3 weeks of age. $A$, Whole-cell voltage-clamp recording of current response to GABA in a GnRH neuron from an adult control female. $\boldsymbol{B}-\boldsymbol{E}$, Representative on-cell recordings of firing response (vertical action currents) to GABA in cells from adult control (B), adult PNA (C), 3-week-old control (D), and 3-week-old PNA female $(\boldsymbol{E})$ mice. $\boldsymbol{A}-\boldsymbol{E}$ are on the same time scale. $\boldsymbol{F}$, Percentage of GnRH neurons that fire in response to GABA. The number of cells studied is shown within each bar (Fisher's exact test for each age group, ${ }^{*} p<0.05$ ). $\mathbf{G}$, Individual values (circles) and mean \pm SEM (crosses) of the magnitude of GABA-induced membrane depolarization (two-way ANOVA/Fisher's LSD; sex/treatment, $F_{(1,56)}=2.3 ;$ age, $F_{(3,56)}=2.4$; interaction, $\left.F_{(3,56)}=2.1\right)$.

Table 10. Baseline membrane potential of GnRH neurons

\begin{tabular}{lll}
\hline Age (weeks) & CON 9 & PNA $\subsetneq$ \\
\hline 2 & $-63.4 \pm 1.9 \mathrm{mV}, n=12$ & $-65.4 \pm 2.9 \mathrm{mV}, n=8$ \\
3 & $-66.3 \pm 1.1 \mathrm{mV}, n=7$ & $-61.9 \pm 1.6 \mathrm{mV}, n=11$ \\
4 & $-63.3 \pm 0.9 \mathrm{mV}, n=7$ & $-63.9 \pm 1.9 \mathrm{mV}, n=7$ \\
$>6$ & $-64.7 \pm 1.8 \mathrm{mV}, n=5$ & $-65.0 \pm 1.4 \mathrm{mV}, n=5$
\end{tabular}

Values are the mean \pm SEM. No differences were observed among groups; treatment, $F_{(1,84)}=0.01$; age, $F_{(4,84)}=0.07$; interaction, $F_{(3,58)}=1.25$.

all GnRH neurons studied at all ages (Fig. 5G). In GnRH neurons from PNA females, however, the magnitude of depolarization was blunted at 3 weeks of age compared with controls $(p<0.05)$.

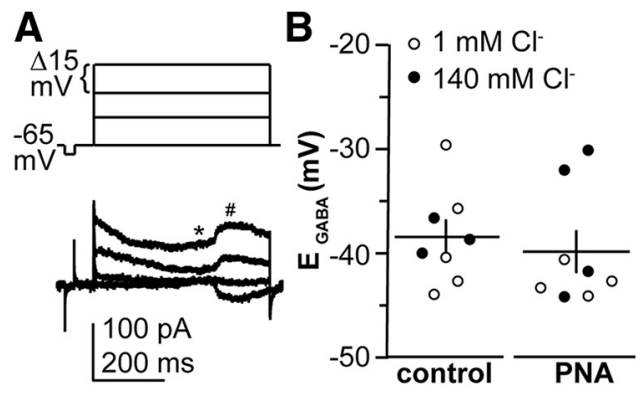

Figure 6. $E_{G A B A}$ is not altered by PNA in GnRH neurons from 3-week-old females. $A$, Top Voltage step protocol from -65 to $-20 \mathrm{mV}$. Bottom, Representative gramicidin perforatedpatch recording showing the current response to voltage steps. * and \# show where measurements were made of baseline and $G A B A_{A} R$-mediated current, respectively. Capacitive transients at the start and end of the variable step protocol were truncated for clarity. $\boldsymbol{B}$, Measurements of $E_{\text {GABA }}$ in control and PNA females. Open and closed circles show recordings using 1 and $140 \mathrm{~mm}$ chloride pipette solutions, respectively. Data were analyzed using two-tailed, unpaired Student's $t$ test, $p=0.7048$.

Reversal potential for $\mathrm{GABA}_{\mathrm{A}}$ receptor-mediated current is not altered by PNA in 3-week-old females

Gramicidin perforated-patch recordings were used to measure the reversal potential for the $\mathrm{GABA}_{\mathrm{A}}$ receptor-mediated current $\left(E_{\mathrm{GABA}} ;\right.$ Fig. 6). $E_{\mathrm{GABA}}$ was not different between control and PNA mice at 3 weeks of age. No difference in $E_{\mathrm{GABA}}$ was observed between measures made using 1 vs $140 \mathrm{~mm}$ chloride pipette solutions, indicating that the measured reversal potentials were dependent on intrinsic chloride concentration and were not contaminated by the recording.

\section{Discussion}

Neuroendocrine changes are present in most women with PCOS, and similar changes have been shown to emerge during puberty in hyperandrogenemic girls (Yoo et al., 2006; Collins et al., 2014). Adult PNA mice recapitulate several features of PCOS and allow neurobiological mechanisms to be examined. GABAergic transmission to GnRH neurons is elevated in these mice in adulthood (Sullivan and Moenter, 2004). GABA levels in CSF from women with PCOS are also higher than controls (Kawwass et al., 2017). We examined the effects of PNA treatment and sex on the development of GABAergic transmission to GnRH neurons and their postsynaptic response to GABA. GABAergic transmission frequency increases during prepubertal development in both sexes. In females, PNA increases transmission frequency during prepubertal development but blunts the excitatory postsynaptic response to GABA in these cells, despite not altering $E_{\mathrm{GABA}}$.

In all groups, low-frequency GABAergic transmission to $\mathrm{GnRH}$ neurons was observed at 1 week of age. Transmission frequency increased to adult levels before outward signs of puberty were observed. The present findings support and extend work showing high-frequency GnRH release in brain slices from postnatal males (Glanowska et al., 2014), and a preliminary report of highfrequency GnRH neuron firing activity in both sexes (Dulka and Moenter, 2016). Together, these observations make a strong case that the GnRH neuronal network is active well before maturation of the downstream reproductive system. This suggests that $\mathrm{GnRH}$ neuron activity during postnatal/pubertal development may have a role beyond reproductive output, such as sculpting formation and stabilization of nascent synapses (Katz and Shatz, 1996; Andreae and Burrone, 2014). The increase in GABAergic transmission to GnRH neurons during prepubertal development likely reflects ongoing synaptogenesis, which occurs primarily during the 
postnatal period in mice. For example, mature synapses in visual and somatosensory cortex increase over a similar period, from postnatal day 4 to 32 (De Felipe et al., 1997; Li et al., 2010).

In females, PNA treatment increased GABAergic transmission to GnRH neurons by 3 weeks of age, a difference that was maintained in adulthood. This increase was activity independent, suggesting that PNA alters synaptic formation and/or pruning. This observation is consistent with increased GABAergic appositions to GnRH neurons in female PNA mice by postnatal day 25 and in adults (Silva et al., 2016). A similar increase in unidentified synaptic contacts to GnRH neurons was observed in adult PNA sheep (Kim et al., 1999). An important caveat to the present work is that some presynaptic terminals are disassociated from sites of action potential generation in brain slices. Likewise, synaptic transmission to $\mathrm{GnRH}$ neuron processes that are not preserved within the slice cannot be detected. There may thus be additional activity-dependent changes in transmission and/or further organizational changes within the whole brain that could not be detected.

In addition to effects on neuronal organization, PNA produces mild hyperandrogenemia in adults (Sullivan and Moenter, 2004; Witham et al., 2012; Moore et al., 2013). In control mice, gonadal biosynthesis of androgens begins around postnatal day 5 in females and prenatally in males (Pointis et al., 1979; Mannan and O'Shaughnessy, 1991); it is not known whether this is altered by PNA. Mild elevations of androgens such as those observed in PCOS and occur in PNA mice upregulate GABA transmission frequency to GnRH neurons (Sullivan and Moenter, 2005), although high androgen doses in models of androgen abuse can reduce transmission (Penatti et al., 2010; Penatti et al., 2011). Differences in transmission observed in PNA mice could thus be attributable to a combination of altered organization and network activation by androgens. It is important to point out that prenatal androgen exposure does not merely masculinize GABAergic transmission; GABAergic transmission in PNA females is greater than control males in both 3-week-old and adult mice. PNA treatment of males also increases GABAergic transmission to $\mathrm{GnRH}$ neurons during prepubertal development, further suggesting that prenatal androgen exposure has developmental effects separate from sex differences. Unlike females, sPSC frequency was not altered by PNA in adult males. This may be attributable to differences in androgen receptor distribution and/or levels at the time of treatment and/or later in development. Endogenous androgen levels likely also differ with sex.

In control mice of both sexes, GABA can excite GnRH neurons throughout the age range examined in the present studies (DeFazio et al., 2002). GnRH neurons from 3-week-old PNA mice receive increased GABA transmission compared with controls, but a preliminary report indicates their firing activity is reduced at this age (Dulka and Moenter, 2016). This discrepancy led us to test the response of GnRH neurons to GABA in female PNA mice. Response in adult PNA mice was similar to controls. In marked contrast, cells from 3-week-old PNA females fired action potentials less often and had blunted membrane depolarization in response to GABA. These observations suggest that there are postsynaptic changes in GnRH neurons from PNA mice that reduce their firing activity despite increased GABA transmission frequency at this age. This is consistent with the observation that neurons can compensate for increased excitatory drive to maintain homeostatic activity levels (Davis and Bezprozvanny, 2001).

There are several possible mechanisms by which such compensation may occur. First, PNA may alter chloride cotransporter function during development. There was no difference, however, in the reversal potential of $\mathrm{GABA}_{\mathrm{A}} \mathrm{R}$-mediated current between 3-week-old control and PNA females, suggesting that any such changes have minimal perisomatic functional impact. Second, PNA may alter voltage-gated sodium channels to modify action potential threshold or increase A-type potassium currents to reduce neuronal excitability and response to synaptic inputs. Of interest with regard to the latter, testosterone increases A-type potassium current to induce arterial vasodilation (Ding and Stallone, 2001; Cairrão et al., 2008). Finally, the higher-frequency GABAergic input in PNA mice may induce short-term effects, such as shunting inhibition or partial inactivation of sodium channels, which would tend to reduce the likelihood of firing. PNA did not alter the amplitude or kinetics of either mPSCs or sPSCS, suggesting that changes in postsynaptic $\mathrm{GABA}_{\mathrm{A}}$ receptors or the number of these receptors activated by endogenous presynaptic GABA release do not contribute to the altered response to GABA. Regardless of the mechanisms involved in reducing the GnRH neuron response to GABA in 3-week-old PNA mice, these are apparently lost during development or become insufficient to reduce firing as there was no effect of PNA on the response to GABA in cells from adults. The loss of these adaptive mechanisms may be an important factor in upregulating GnRH neuron output in adult PNA mice and possibly in women with PCOS.

The effects of PNA are most likely dependent upon activation of androgen receptors, as the nonaromatizable androgen DHT was used. In the hippocampus, androgens increase synaptic spines (Brawer et al., 1983; Hajszan et al., 2007, 2008; Hatanaka et al., 2015) and synaptic transmission during pubertal development (Pettorossi et al., 2013). Additionally, glia express androgen receptor and play key roles in synapse formation and regulation (García-Segura et al., 1994; Tasker et al., 2012). Within the hypothalamus, many kisspeptin neurons in the arcuate and anteroventral periventricular nuclei are GABAergic (Cravo et al., 2011); these cells project to $\mathrm{GnRH}$ neurons, at least in part, to convey steroid feedback (Wintermantel et al., 2006). Adult males and females express androgen receptors in arcuate and anteroventral periventricular kisspeptin neurons (Smith et al., 2005; Iwata et al., 2017). In males, this expression begins in utero in arcuate neurons, but it is unknown when expression begins in females (Kumar et al., 2015). The PNA-induced changes in synaptic organization may arise from increased connectivity with typical afferent populations such as those expressing kisspeptin and/or recruitment of additional GABAergic afferents. Although the effects of DHT are most likely through androgen receptors, we cannot rule out additional effects through the activation of estrogen receptor $\beta(\mathrm{ER} \beta)$ by DHT metabolites (Lund et al., 2006). $\mathrm{ER} \beta$ is expressed in GnRH neurons, and its activation increases activity in these cells (Hrabovszky et al., 2000; Chu et al., 2009).

Although there were clear differences in GABAergic transmission to GnRH neurons among treatments, frequency was variable, particularly in groups with higher frequencies. Both biological and technical factors may contribute to this. Differences during development may be attributable to the variable timing of pubertal maturation in individual mice, and even among cells within an animal. The pattern of GABAergic transmission may change over time to help drive episodic GnRH release. Typical GnRH release intervals are long compared with the duration of recordings, and cells may be in different phases when examined, contributing to a range of PSC frequencies. GABAergic populations afferent to $\mathrm{GnRH}$ neurons may also have different sensitivities to programming and/or activational effects of androgens. 
Prepubertal development is a critical period during which the changes in GnRH neurons and their afferent network may affect the regulation of the reproductive system in adults. The increase in GABAergic transmission frequency to these cells and a concomitant decrease in their responsiveness to GABA that arise before reproductive maturity in PNA females, and the subsequent loss of the postsynaptic compensation, may contribute to pathological neuroendocrine features of PNA mice and perhaps of women with PCOS.

\section{References}

Abbott DH, Barnett DK, Bruns CM, Dumesic DA (2005) Androgen excess fetal programming of female reproduction: a developmental aetiology for polycystic ovary syndrome? Hum Reprod Update 11:357-374. CrossRef Medline

Andreae LC, Burrone J (2014) The role of neuronal activity and transmitter release on synapse formation. Curr Opin Neurobiol 27:47-52. CrossRef Medline

Auger C, Marty A (2000) Quantal currents at single-site central synapses. J Physiol 526:3-11. CrossRef Medline

Baird DT, Swanston I, Scaramuzzi RJ (1976) Pulsatile release of LH and secretion of ovarian steroids in sheep during the luteal phase of the estrous cycle. Endocrinology 98:1490-1496. CrossRef Medline

Birch RA, Padmanabhan V, Foster DL, Unsworth WP, Robinson JE (2003) Prenatal programming of reproductive neuroendocrine function: fetal androgen exposure produces progressive disruption of reproductive cycles in sheep. Endocrinology 144:1426-1434. CrossRef Medline

Blank SK, McCartney CR, Marshall JC (2006) The origins and sequelae of abnormal neuroendocrine function in polycystic ovary syndrome. Hum Reprod Update 12:351-361. CrossRef Medline

Brawer J, Schipper H, Robaire B (1983) Effects of long term androgen and estradiol exposure on the hypothalamus. Endocrinology 112:194-199. CrossRef Medline

Burt Solorzano CM, Beller JP, Abshire MY, Collins JS, McCartney CR, Marshall JC (2012) Neuroendocrine dysfunction in polycystic ovary syndrome. Steroids 77:332-337. CrossRef Medline

Cairrão E, Alvarez E, Santos-Silva AJ, Verde I (2008) Potassium channels are involved in testosterone-induced vasorelaxation of human umbilical artery. Naunyn Schmiedebergs Arch Pharmacol 376:375-383. CrossRef Medline

Cheong RY, Czieselsky K, Porteous R, Herbison AE (2015) Expression of ESR1 in glutamatergic and GABAergic neurons is essential for normal puberty onset, estrogen feedback, and fertility in female mice. J Neurosci 35:14533-14543. CrossRef Medline

Christian CA, Moenter SM (2007) Estradiol induces diurnal shifts in GABA transmission to gonadotropin-releasing hormone neurons to provide a neural signal for ovulation. J Neurosci 27:1913-1921. CrossRef Medline

Chu Z, Moenter SM (2005) Endogenous activation of metabotropic glutamate receptors modulates GABAergic transmission to gonadotropinreleasing hormone neurons and alters their firing rate: a possible local feedback circuit. J Neurosci 25:5740-5749. CrossRef Medline

Chu Z, Andrade J, Shupnik MA, Moenter SM (2009) Differential regulation of gonadotropin-releasing hormone neuron activity and membrane properties by acutely applied estradiol: dependence on dose and estrogen receptor subtype. J Neurosci 29:5616-5627. CrossRef Medline

Clarke IJ, Cummins JT (1982) The temporal relationship between gonadotropin releasing hormone $(\mathrm{GnRH})$ and luteinizing hormone $(\mathrm{LH})$ secretion in ovariectomized ewes. Endocrinology 111:1737-1739. CrossRef Medline

Collins JS, Beller JP, Burt Solorzano C, Patrie JT, Chang RJ, Marshall JC, McCartney CR (2014) Blunted day-night changes in luteinizing hormone pulse frequency in girls with obesity: the potential role of hyperandrogenemia. J Clin Endocrinol Metab 99:2887-2896. CrossRef Medline

Cravo RM, Margatho LO, Osborne-Lawrence S, Donato J Jr, Atkin S, Bookout AL, Rovinsky S, Frazão R, Lee CE, Gautron L, Zigman JM, Elias CF (2011) Characterization of Kiss1 neurons using transgenic mouse models. Neuroscience 173:37-56. CrossRef Medline

Davis GW, Bezprozvanny I (2001) Maintaining the stability of neural function: a homeostatic hypothesis. Annu Rev Physiol 63:847-869. CrossRef Medline

DeFazio RA, Heger S, Ojeda SR, Moenter SM (2002) Activation of A-type gamma-aminobutyric acid receptors excites gonadotropin-releasing hormone neurons. Mol Endocrinol 16:2872-2891. CrossRef Medline

DeFazio RA, Elias CF, Moenter SM (2014) GABAergic transmission to kisspeptin neurons is differentially regulated by time of day and estradiol in female mice. J Neurosci 34:16296-16308. CrossRef Medline
De Felipe J, Marco P, Fairén A, Jones EG (1997) Inhibitory synaptogenesis in mouse somatosensory cortex. Cereb Cortex 7:619-634. CrossRef Medline

Ding AQ, Stallone JN (2001) Testosterone-induced relaxation of rat aorta is androgen structure specific and involves $\mathrm{K}+$ channel activation. J Appl Physiol (1985) 91:2742-2750. CrossRef Medline

Dulka EA, Moenter SM (2017) Prepubertal development of gonadotropinreleasing hormone neuron activity is altered by sex, age, and prenatal androgen exposure. Endocrinology 158:3943-3953. CrossRef Medline

Foecking EM, Szabo M, Schwartz NB, Levine JE (2005) Neuroendocrine consequences of prenatal androgen exposure in the female rat: absence of luteinizing hormone surges, suppression of progesterone receptor gene expression, and acceleration of the gonadotropin-releasing hormone pulse generator. Biol Reprod 72:1475-1483. CrossRef Medline

Fricker D, Verheugen JA, Miles R (1999) Cell-attached measurements of the firing threshold of rat hippocampal neurones. The Journal of physiology 517:791-804. CrossRef Medline

García-Segura LM, Chowen JA, Párducz A, Naftolin F (1994) Gonadal hormones as promoters of structural synaptic plasticity: cellular mechanisms. Prog Neurobiol 44:279-307. CrossRef Medline

Glanowska KM, Moenter SM (2015) Differential regulation of GnRH secretion in the preoptic area (POA) and the median eminence (ME) in male mice. Endocrinology 156:231-241. CrossRef Medline

Glanowska KM, Burger LL, Moenter SM (2014) Development of gonadotropin-releasing hormone secretion and pituitary response. J Neurosci 34:15060-15069. CrossRef Medline

Goodarzi MO, Dumesic DA, Chazenbalk G, Azziz R (2011) Polycystic ovary syndrome: etiology, pathogenesis and diagnosis. Nat Rev Endocrinol 7:219-231. CrossRef Medline

Haisenleder DJ, Dalkin AC, Ortolano GA, Marshall JC, Shupnik MA (1991) A pulsatile gonadotropin-releasing hormone stimulus is required to increase transcription of the gonadotropin subunit genes: evidence for differential regulation of transcription by pulse frequency in vivo. Endocrinology 128:509-517. CrossRef Medline

Hajszan T, MacLusky NJ, Johansen JA, Jordan CL, Leranth C (2007) Effects of androgens and estradiol on spine synapse formation in the prefrontal cortex of normal and testicular feminization mutant male rats. Endocrinology 148:1963-1967. CrossRef Medline

Hajszan T, MacLusky NJ, Leranth C (2008) Role of androgens and the androgen receptor in remodeling of spine synapses in limbic brain areas. Horm Behav 53:638-646. CrossRef Medline

Hatanaka Y, Hojo Y, Mukai H, Murakami G, Komatsuzaki Y, Kim J, Ikeda M, Hiragushi A, Kimoto T, Kawato S (2015) Rapid increase of spines by dihydrotestosterone and testosterone in hippocampal neurons: dependence on synaptic androgen receptor and kinase networks. Brain Res 1621:121-132. CrossRef Medline

Herbison AE, Moenter SM (2011) Depolarising and hyperpolarising actions of $\mathrm{GABA}(\mathrm{A})$ receptor activation on gonadotrophin-releasing hormone neurones: towards an emerging consensus. J Neuroendocrinol 23:557569. CrossRef Medline

Hrabovszky E, Shughrue PJ, Merchenthaler I, Hajszán T, Carpenter CD, Liposits Z, Petersen SL (2000) Detection of estrogen receptor-beta messenger ribonucleic acid and 125I-estrogen binding sites in luteinizing hormone-releasing hormone neurons of the rat brain. Endocrinology 141:3506-3509. CrossRef Medline

Huang X, Harlan RE (1993) Absence of androgen receptors in LHRH immunoreactive neurons. Brain Res 624:309-311. CrossRef Medline

Iwata K, Kunimura Y, Matsumoto K, Ozawa H (2017) Effect of androgen on Kiss1 expression and luteinizing hormone release in female rats. J Endocrinol 233:281-292. CrossRef Medline

Kaeser PS, Regehr WG (2014) Molecular mechanisms for synchronous, asynchronous, and spontaneous neurotransmitter release. Annu Rev Physiol 76:333-363. CrossRef Medline

Katz LC, Shatz CJ (1996) Synaptic activity and the construction of cortical circuits. Science 274:1133-1138. CrossRef Medline

Kawwass JF, Sanders KM, Loucks TL, Rohan LC, Berga SL (2017) Increased cerebrospinal fluid levels of GABA, testosterone and estradiol in women with polycystic ovary syndrome. Hum Reprod 32:1450-1456. CrossRef Medline

Kim SJ, Foster DL, Wood RI (1999) Prenatal testosterone masculinizes synaptic input to gonadotropin-releasing hormone neurons in sheep. Biol Reprod 61:599-605. CrossRef Medline

Kumar D, Periasamy V, Freese M, Voigt A, Boehm U (2015) In utero devel- 
opment of kisspeptin/GnRH neural circuitry in male mice. Endocrinology 156:3084-3090. CrossRef Medline

Leipheimer RE, Bona-Gallo A, Gallo RV (1984) The influence of progesterone and estradiol on the acute changes in pulsatile luteinizing hormone release induced by ovariectomy on diestrus day 1 in the rat. Endocrinology 114:1605-1612. CrossRef Medline

Li M, Cui Z, Niu Y, Liu B, Fan W, Yu D, Deng J (2010) Synaptogenesis in the developing mouse visual cortex. Brain Res Bull 81:107-113. CrossRef Medline

Lund TD, Hinds LR, Handa RJ (2006) The androgen $5 \alpha$-dihydrotestosterone and its metabolite $5 \alpha$-androstan- $3 \beta, 17 \beta$-diol inhibit the hypothalamo-pituitary-adrenal response to stress by acting through estrogen receptor $\beta$-expressing neurons in the hypothalamus. J Neurosci 26:1448-1456. CrossRef Medline

Mannan MA, O’Shaughnessy PJ (1991) Steroidogenesis during postnatal development in the mouse ovary. J Endocrinol 130:101-106. CrossRef Medline

McCartney CR, Marshall JC (2016) Polycystic ovary syndrome. N Engl J Med 375:1398-1399. CrossRef Medline

McCartney CR, Gingrich MB, Hu Y, Evans WS, Marshall JC (2002) Hypothalamic regulation of cyclic ovulation: evidence that the increase in gonadotropin-releasing hormone pulse frequency during the follicular phase reflects the gradual loss of the restraining effects of progesterone. J Clin Endocrinol Metab 87:2194-2200. CrossRef Medline

Moenter SM, Caraty A, Karsch FJ (1990) The estradiol-induced surge of gonadotropin-releasing hormone in the ewe. Endocrinology 127:13751384. CrossRef Medline

Moenter SM, Brand RM, Midgley AR, Karsch FJ (1992) Dynamics of gonadotropin-releasing hormone release during a pulse. Endocrinology 130:503-510. CrossRef Medline

Moore AM, Prescott M, Campbell RE (2013) Estradiol negative and positive feedback in a prenatal androgen-induced mouse model of polycystic ovarian syndrome. Endocrinology 154:796-806. CrossRef Medline

Moore AM, Prescott M, Marshall CJ, Yip SH, Campbell RE (2015) Enhancement of a robust arcuate GABAergic input to gonadotropinreleasing hormone neurons in a model of polycystic ovarian syndrome. Proc Natl Acad Sci U S A 112:596-601. CrossRef Medline

Nippoldt TB, Reame NE, Kelch RP, Marshall JC (1989) The roles of estradiol and progesterone in decreasing luteinizing hormone pulse frequency in the luteal phase of the menstrual cycle. J Clin Endocrinol Metab 69:6776. CrossRef Medline

Pastor CL, Griffin-Korf ML, Aloi JA, Evans WS, Marshall JC (1998) Polycystic ovary syndrome: evidence for reduced sensitivity of the gonadotropin-releasing hormone pulse generator to inhibition by estradiol and progesterone. J Clin Endocrinol Metab 83:582-590. CrossRef Medline

Paxinos G, Franklin K (2001) The mouse brain in stereotaxic coordinates, Ed 4. San Diego, CA: Academic.

Penatti CA, Davis MC, Porter DM, Henderson LP (2010) Altered GABA receptor-mediated synaptic transmission disrupts the firing of gonadotropin-releasing hormone neurons in male mice under conditions that mimic steroid abuse. J Neurosci 30:6497-6506. CrossRef Medline

Penatti CA, Oberlander JG, Davis MC, Porter DM, Henderson LP (2011) Chronic exposure to anabolic androgenic steroids alters activity and synaptic function in neuroendocrine control regions of the female mouse. Neuropharmacology 61:653-664. CrossRef Medline

Petersen SL, Ottem EN, Carpenter CD (2003) Direct and indirect regulation of gonadotropin-releasing hormone neurons by estradiol. Biol Reprod 69:1771-1778. CrossRef Medline

Pettorossi VE, Di Mauro M, Scarduzio M, Panichi R, Tozzi A, Calabresi P, Grassi S (2013) Modulatory role of androgenic and estrogenic neurosteroids in determining the direction of synaptic plasticity in the CA1 hippocampal region of male rats. Physiol Rep 1:e00185. CrossRef Medline

Pielecka-Fortuna J, Moenter SM (2010) Kisspeptin increases gammaaminobutyric acidergic and glutamatergic transmission directly to gonadotropin-releasing hormone neurons in an estradiol-dependent manner. Endocrinology 151:291-300. CrossRef Medline

Pointis G, Latreille MT, Mignot TM, Janssens Y, Cedard L (1979) Regulation of testosterone synthesis in the fetal mouse testis. J Steroid Biochem 11:1609-1612. CrossRef Medline

Roland AV, Moenter SM (2011) Prenatal androgenization of female mice programs an increase in firing activity of gonadotropin-releasing hormone $(\mathrm{GnRH})$ neurons that is reversed by metformin treatment in adulthood. Endocrinology 152:618-628. CrossRef Medline
Ruka KA, Burger LL, Moenter SM (2016) Both estrogen and androgen modify the response to activation of neurokinin-3 and kappa-opioid receptors in arcuate kisspeptin neurons from male mice. Endocrinology 157:752-763. CrossRef Medline

Shayya R, Chang RJ (2010) Reproductive endocrinology of adolescent polycystic ovary syndrome. BJOG 117:150-155. CrossRef Medline

Silva MS, Prescott M, Campbell RE (2016) Development of GABAergic altered brain wiring and plasticity in a mouse model of polycystic ovary syndrome (PCOS). Soc Neurosci Abstr 42:60.19.

Skinner DC, Caraty A, Allingham R (2001) Unmasking the progesterone receptor in the preoptic area and hypothalamus of the ewe: no colocalization with gonadotropin-releasing hormone neurons. Endocrinology 142: 573-579. CrossRef Medline

Smith JT, Dungan HM, Stoll EA, Gottsch ML, Braun RE, Eacker SM, Clifton DK, Steiner RA (2005) Differential regulation of KiSS-1 mRNA expression by sex steroids in the brain of the male mouse. Endocrinology 146: 2976-2984. CrossRef Medline

Succol F, Fiumelli H, Benfenati F, Cancedda L, Barberis A (2012) Intracellular chloride concentration influences the $\mathrm{GABA}_{\mathrm{A}}$ receptor subunit composition. Nat Commun 3:738. CrossRef Medline

Sullivan SD, Moenter SM (2004) Prenatal androgens alter GABAergic drive to gonadotropin-releasing hormone neurons: implications for a common fertility disorder. Proc Natl Acad Sci U S A 101:7129-7134. CrossRef Medline

Sullivan SD, Moenter SM (2005) GABAergic integration of progesterone and androgen feedback to gonadotropin-releasing hormone neurons. Biol Reprod 72:33-41. CrossRef Medline

Sullivan SD, DeFazio RA, Moenter SM (2003) Metabolic regulation of fertility through presynaptic and postsynaptic signaling to gonadotropinreleasing hormone neurons. J Neurosci 23:8578-8585. Medline

Suter KJ, Song WJ, Sampson TL, Wuarin JP, Saunders JT, Dudek FE, Moenter SM (2000) Genetic targeting of green fluorescent protein to gonadotropin-releasing hormone neurons: characterization of whole-cell electrophysiological properties and morphology. Endocrinology 141: 412-419. CrossRef Medline

Tasker JG, Oliet SH, Bains JS, Brown CH, Stern JE (2012) Glial regulation of neuronal function: from synapse to systems physiology. J Neuroendocrinol 24:566-576. CrossRef Medline

Tilbrook AJ, de Kretser DM, Cummins JT, Clarke IJ (1991) The negative feedback effects of testicular steroids are predominantly at the hypothalamus in the ram. Endocrinology 129:3080-3092. CrossRef Medline

Verheugen JA, Fricker D, Miles R (1999) Noninvasive measurements of the membrane potential and GABAergic action in hippocampal interneurons. J Neurosci 19:2546-2555. Medline

Watson RE Jr, Langub MC Jr, Landis JW (1992) Further evidence that most luteinizing hormone-releasing hormone neurons are not directly estrogen-responsive: simultaneous localization of luteinizing hormonereleasing hormone and estrogen receptor Immunoreactivity in the guinea-pig brain. J Neuroendocrinol 4:311-317. CrossRef Medline

Wildt L, Häusler A, Marshall G, Hutchison JS, Plant TM, Belchetz PE, Knobil E (1981) Frequency and amplitude of gonadotropin-releasing hormone stimulation and gonadotropin secretion in the rhesus monkey. Endocrinology 109:376-385. CrossRef Medline

Wintermantel TM, Campbell RE, Porteous R, Bock D, Gröne HJ, Todman MG, Korach KS, Greiner E, Pérez CA, Schütz G, Herbison AE (2006) Definition of estrogen receptor pathway critical for estrogen positive feedback to gonadotropin-releasing hormone neurons and fertility. Neuron 52:271-280. CrossRef Medline

Witham EA, Meadows JD, Shojaei S, Kauffman AS, Mellon PL (2012) Prenatal exposure to low levels of androgen accelerates female puberty onset and reproductive senescence in mice. Endocrinology 153:4522-4532. CrossRef Medline

Yoo RY, Dewan A, Basu R, Newfield R, Gottschalk M, Chang RJ (2006) Increased luteinizing hormone pulse frequency in obese oligomenorrheic girls with no evidence of hyperandrogenism. Fertil Steril 85:1049-1056. CrossRef Medline

Zeleznik AJ, Fairchild-Benyo D (1994) Control of follicular development, corpus luteum function, and the recognition of pregnancy in higher primates. In: The physiology of reproduction (Knobil E, Neill JD, eds), pp 751-782. New York, NY: Raven. 